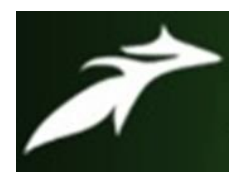

Arish Khan et al, International Journal of Advances in Agricultural Science and Technology,

Vol.8 Issue.8, August-2021, pg. 87-92

\title{
Problems of Women Self Help Group Members in Kota District of Rajasthan
}

\author{
Arish Khan ${ }^{1}$; Dr. Sanjay Kumar ${ }^{2}$; Vikas Singh ${ }^{3}$ \\ Department of Agricultural Economics, (Naini Agricultural Institute), Sam Higginbottom University of \\ Agricultural, Technology and Sciences, Prayagraj-211 007, Uttar Pradesh, India \\ 1*Research Scholar (arishkhan.ag@gmail.com); ${ }^{2}$ Assistant Professor; ${ }^{3} \mathrm{Ph} . \mathrm{D}$. Scholar \\ DOI: 10.47856/ijaast.2021.v08i8.009
}

\begin{abstract}
:
Rural women play vital function in carrying out the transformational, financial, conservational and social changes required for sustainable growth. Restriction on get right of entry to credit score, poor health care management and literacy rate are the problems they face. Women empowerment is the important thing now no longer simplest to the welfare of character individuals of the own circle of relatives and rural communities, however additionally to common economic increase of the nation. Half of the arena's populace is represented with the aid of using ladies and till they're given the same possibilities society cannot gain increase. Government, society and non - governmental organizations (NGOs) round the arena come ahead and take crucial steps to empower ladies and supply them the same rights in monetary and non-monetary improvement. Therefore, that is the perfect time to shift from welfare mode to empowerment mode in governmental regulations designed for the development of ladies. To empower women's continuous efforts taken with the aid of using Indian authorities and National Bank for Agricultural and Rural Development (NABARD) via microfinance raised the popular of residing of negative ladies and their family members above poverty line to a few extents. Therefore, the tasks have to recognition on the above stated problems confronted with the aid of using ladies. In this way, this paper is analyzed with self-assist group's rural women empowerment and satisfaction via micro credit in Kota District
\end{abstract}

\section{Introduction}

Poverty is the biggest problem faced by any developing country as it hinders growth of the economy and standard of living of the people. So the prime activity of the Government of India is alleviation of poverty, and for that different programmes are adopted from time to time. Poor people suffer from the negligence of formal financial institutions, due to lack of collaterals, the high transaction cost of giving a small amount of loan to a large number of people and poor credit history. Negligible amount of income and its irregularity is the main reason of the financial exclusion of rural poor. Inaccessibility of formal banking system and the influence of informal finance to the rural population forced authorities to think about an alternative source to fulfil their financial needs. So with a view to 


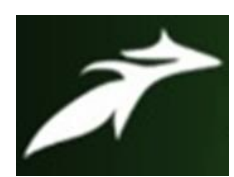

Arish Khan et al, International Journal of Advances in Agricultural Science and Technology,

Vol.8 Issue.8, August-2021, pg. 87-92

ISSN: 2348-1358

Impact Factor: 6.057

NAAS Rating: 3.77

support this disadvantaged population, the micro finance movement is institutionalised by the Government to give financial support to the rural poor, mainly, rural women. Financial assistance given to women is better utilised than in men. Among many activities such as better education to children and health care, various pension schemes have been introduced by the Government, and microfinance programmes to alleviate poverty through SHGs is one of the prominent approaches to address the issue of rural poverty.

Microcredit is the extension of very small loans (microloans) to poor borrowers who typically lack collateral, steady employment and a verifiable credit history. It is designed to spur entrepreneurship, increase incomes, alleviate poverty and often also to empower women. Microcredit is a part of microfinance, which is the provision of a wider range of financial services, in particular savings, to the poor. Micro-credit financing system uses the social trust as the collateral. Loans are given to individuals, but an entire group is responsible for the repayment. Hence, the borrower who does not fulfil his commitment to repay back will lose his/her social capital. Today, there are millions of poor people around the world who turn to be entrepreneurs through the micro-credit sector.

\section{Objectives of the Study}

1. To analyse the problems of rural women of SHG's members.

2. To offer suggestions to improve the satisfaction of women entrepreneurs.

\section{Scope of the Study}

The study is undertaken to assess the role of institution in developing the rural women entrepreneurs and contributing towards to the economic development of India. The current research helps to know the challenges of SHG's that were faced by the rural women entrepreneurs in Kota district of Rajasthan. The study is confined to the members of the SHG's.

\section{Limitations of the Study}

1. Due to lack of time, the number of respondents as well as study was restricted only to thirteen villages of Kota district.

2. Few members of the group were hesitated to respond to the questions asked by the researcher.

3. The study is confined to the members of the SHG's

\section{Statement of the Problem}

Rural women are the most marginalized community, which keep them away from formal financial sources and social activities. Microcredit is the most powerful tool for women empowerment and facilitates them to meet their life cycle requirements. Microcredit helps them to access monetary services in a better manner. The concept of microcredit put in to practice through Self Help Groups, where members started to pool up their small savings and distribute funds among members with low interest. Microcredit movements give opportunities to poor women through their concerned SHGs to participate in income generating and several social activities. This will help them to become 


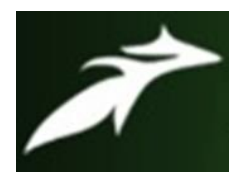

Arish Khan et al, International Journal of Advances in Agricultural Science and Technology,

Vol.8 Issue.8, August-2021, pg. 87-92

ISSN: 2348-1358

Impact Factor: 6.057

NAAS Rating: 3.77

empowered in different dimensions of their life. It helps poor people in the backward areas to come forward and enjoy better living conditions. In this situation an evaluation is required for assessing the impact of microcredit. Hence the present study was attempted to understand the problems faced by SHG women empowerment in Kota district of Rajasthan.

Poornima and Ramanaiah (2019) in their study identified that no stable price for the products manufactured, lack of practical knowledge and marketing problems are the prominent problems faced by SHG Entrepreneurs.

Pathak et al. (2019) in their study identified that group conflict, lack of interest in taking responsibility among SHG members and lack of motivation are the serious problems exists.

Kumawat and Bansal (2018) in their study ascertained that inadequate training facilities, problems in marketing the products, poor support from financial institutions etc. are the problems faced by SHG members.

Sivakumar and Kavithasri (2017) in their study ascertained that lack of formal education, family responsibilities, lack of communication skills, heavy competition are the problems faced by SHG members

Vinodha Devi (2017) in her study identified that scarcity of raw materials for production, followed by shortage of power, insufficient finance for promoting and running an enterprise etc. are the problems faced by women entrepreneurs.

Kumar et al. (2014) studied the various constraints experienced by rural women in SHG under production, processing, marketing and technical sectors. The most problematic production constraint were high cost of concentrates and non-availability of veterinary services. The most severe processing problem was lack of knowledge on processing technology and lack of storage facility. The most problematic marketing problem was non-availability of scientific storage facility in villages and low price of milk. Problem of more incidence of severe disease was the most problematic technical problem.

Torri (2010) addressed the various problems like lack of coordination and communication between group members, lower caste and social status have further inhibited entry into group entrepreneurial occupations, which in turn limited their economic activities leading to ultimate closure of the groups.

Ravindra (2010) identified the problems faced by the SHGs like illiteracy of the members, lack of proper leadership, dual financing, high rate of interest on bank loan, the problem of low technology, problem of marketing, etc. 


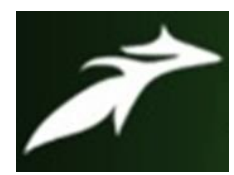

Arish Khan et al, International Journal of Advances in Agricultural Science and Technology,

Vol.8 Issue.8, August-2021, pg. 87-92

ISSN: 2348-1358

Impact Factor: 6.057

NAAS Rating: 3.77

\section{Research Methodology (Year of Study 2021) \\ Area of Study:}

Kota District has been selected purposively for the research work since it is one of the major districts in the State where NRLM scheme can be studied. There are 5 blocks in Kota District out of which Ladpura and Digod Block was selected purposively. Out of all the villages 13 were selected purposely for the present study.

\section{Data Collection and Sampling Techniques:}

This study is based on primary data which was collected with the help of Questionnaire. Multi stage stratified cum purposive sampling design will be used to select district, block, villages, beneficiaries and non- beneficiaries in the ultimate stage of study. A total number of 100 respondents were taken, out of these 50 borrower respondents were selected from the 13 villages of the Ladpura block and 5 villages of the Digod Block and 50 non-borrower respondents were selected from 13 villages of the Ladpura Block and 5 villages of the Digod block.

\section{Tools of Analysis:}

Garret ranking is used to rank the preference indicated by the respondents on different factors.

\section{Analysis and Interpretation}

Table.1Problems faced by members of SHGs

\begin{tabular}{|c|c|c|c|}
\hline S.No. & Constraints/Particulars & Score & Rank \\
\hline $\mathbf{1}$ & Lack of men confidence to women & 63.27 & III \\
\hline $\mathbf{2}$ & Gender dominance & 73.35 & I \\
\hline $\mathbf{3}$ & Much busy to work at home & 69.10 & II \\
\hline $\mathbf{4}$ & Less literacy & 57.75 & IV \\
\hline $\mathbf{5}$ & Lack of employment opportunity to women & 47.79 & V \\
\hline $\mathbf{6}$ & Lack of confidence of women together & 44.47 & VI \\
\hline $\mathbf{7}$ & Lack of marketing facilities & 42.08 & VII \\
\hline $\mathbf{8}$ & Lack of self-confidence of women & 31.97 & VIII \\
\hline $\mathbf{9}$ & More competition for same work/products & 29.76 & IX \\
\hline
\end{tabular}




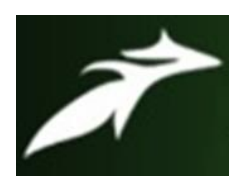

Arish Khan et al, International Journal of Advances in Agricultural Science and Technology,

Vol.8 Issue.8, August-2021, pg. 87-92

ISSN: 2348-1358

Impact Factor: 6.057

NAAS Rating: 3.77

- From the table.1, it is evident thatMajor concern for Rural women was gender dominance and it ranked first with garret score 73.35, second important concern was being much busy to work at home with score 69.10. Lack of men confidence to women, less literacy, lack of employment opportunity to women, lack of confidence of women together, lack of marketing facilities, lack of self-confidence of women and more competition for same work/products were in third, fourth, fifth, sixth, seventh, eighth and ninth rank with average score of 63.27, $57.75,47.79,44.47,42.08,31.97$ and 29.76 respectively.

\section{Suggestions}

- Educational institutions and voluntary organizations should come forward in educating women SHG members to improve their managerial ability and to remove their ignorance and creating awareness.

- Banks and financial institutions are to avoid frequent change in formalities for availing funds from their institutions. If they carry out any change in procedures, it should be properly communicated to the SHG members.

- District Industries Centres(DICs) is expected to offer more training programmes for the development of entrepreneurs. SHG Women entrepreneurs should make use of such training programmes conducted by DICs and improve their production methods, marketing skills, etc.

- Success of entrepreneurs depends not only on their individual ability and skill but also with necessary support extended by their family members. Thus, family members should offer necessary support (i.e.) male members should voluntarily take up and share the family responsibilities.

- Banks and financial institutions should fix repayment period for SHG members in accordance with periodicity of returns.

- Marketing product is one of the main problems for rural women entrepreneurs of SHG's members. Here, informally the members of the SHGs can take responsibility for sales \& promotion activities and even further women co-operative societies can be started to procure the products from women entrepreneurs. They will help them in selling their products.

- Training institutes like RCT should be built in more numbers or staff should be increased so that at a same time more respondents will get trainings regarding product-making or enterprises.

- Focus on "vocal for local" i.e. instead of using imported products people should focus on purchase of local products. E.g. Instead of using Coca-cola drinks people can buy Pan Juices, Orange juices, Lemon juices etc. which are more refreshing and not harmful which are made locally by SHGs women.

\section{Conclusion}

The SHG's play a vital role in the development of the rural women entrepreneurship but still they need capacity building and training in functional areas such as finance, literacy skills, marketing, production and managerial skills. But above all gender equality have to be established in the rural areas just like in urban areas to make rural women entrepreneurial. Business training programmes are the important problems of women entrepreneurs in Kota District.For sustainable progress in living standards of women members of SHGs, Government efforts alone will not give the desired result. Hence voluntary efforts by educational institutions, social clubs and other voluntary organizations 


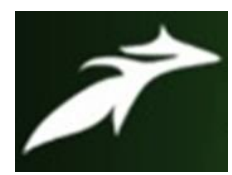

Arish Khan et al, International Journal of Advances in Agricultural Science and Technology,

Vol.8 Issue.8, August-2021, pg. 87-92

ISSN: $2348-1358$

Impact Factor: 6.057

NAAS Rating: 3.77

should come forward for providing necessary training and improving the skills of members of SHGs. Therefore co-ordinated efforts of Government and others would certainly improve the standard of living of women SHG members.

\section{References}

[1]. Poornima and Ramanaiah (2019), A Study on Entrepreneurial Challenges faced by Women SHG Members with Special Reference to Kolar. New Horizon International Journal of Management \& Research. 7: 51-64

[2]. Kumawat, P. and Bansal, V. (2018), A Study on Problems Faced by SHG Members in carryout the SHG Activities. International Journal of Current Microbiology and Applied Sciences. 7(1):420-423.

[3]. Pathak et al. (2019), Study on Major Problem faced by SHG Members and their Perception towards SHGPIS. Plant Archives. 19(1): 1080-1082.

[4]. Sivakumar and Kavithasri (2017), Problems faced by the members of self- help groups with special reference to Thimmampalayam area in Coimbatore district. International Journal of Applied Research. 3(9): 593-598.

[5]. Torri, M. (2010), Community gender entrepreneurship and self-help groups: a way forward to foster social capital and truly effective forms of participation among rural poor women. Community Development Journal, Retrieved 7 May 2010 from Blackwell Publishing, Ltd.

[6]. Vinodha, D. (2017), Challenges faced by Women Entrepreneurs: A Study on Women SHGS in Tamilnadu. Paripex Indian Journal of Research. 6(4): 464-465 